\title{
4. Distant, disconnected and in danger Are educators doing enough to prepare students for frontline freelance risks?
}

\begin{abstract}
For anyone who has worked in another country, the journalistic 'rules of engagement' differ in each port. Foreign correspondents argue passionately for the freedom of the press, saying that by 'bearing witness' to crimes against civilians they will be able to effect change. However, in taking risks to report on such events, most journalists recognise that - if their reports displease a particular country's power elite - they can quickly find themselves deported, banned from future entry, languishing behind bars or, in a worst-case scenario, killed. Using Bourdieuan considerations, this article concentrates on the young, mostly freelance, journalists who have absorbed Western news values - including the myth of the heroic war reporter and truth-seeker-and suggests greater understanding of the cultural and political nuances of countries from which they intend to report. Using journalism as a methodology, this article looks at several cases in which reporters have found themselves in difficulties, and suggests that educators consider sharing three lessons: know your employer; acknowledge local differences between countries; and learn the skill of risk assessment. Risk-assessment skills include stressing the need for sufficient pre-deployment training in first aid, personal safety, security and other protocols and, most importantly, managing exposure to traumatic situations.
\end{abstract}

Keywords: conflict reporting, foreign journalist, freelance journalists, newsgathering, peer support, psychological health, safety, trauma, violence and the press

\section{ALEXANDRA WAKE \\ RMIT University, Melbourne}

\section{Introduction}

Journalists are no longer on the front lines. We are the front lines. (Peter Greste, 2014). 


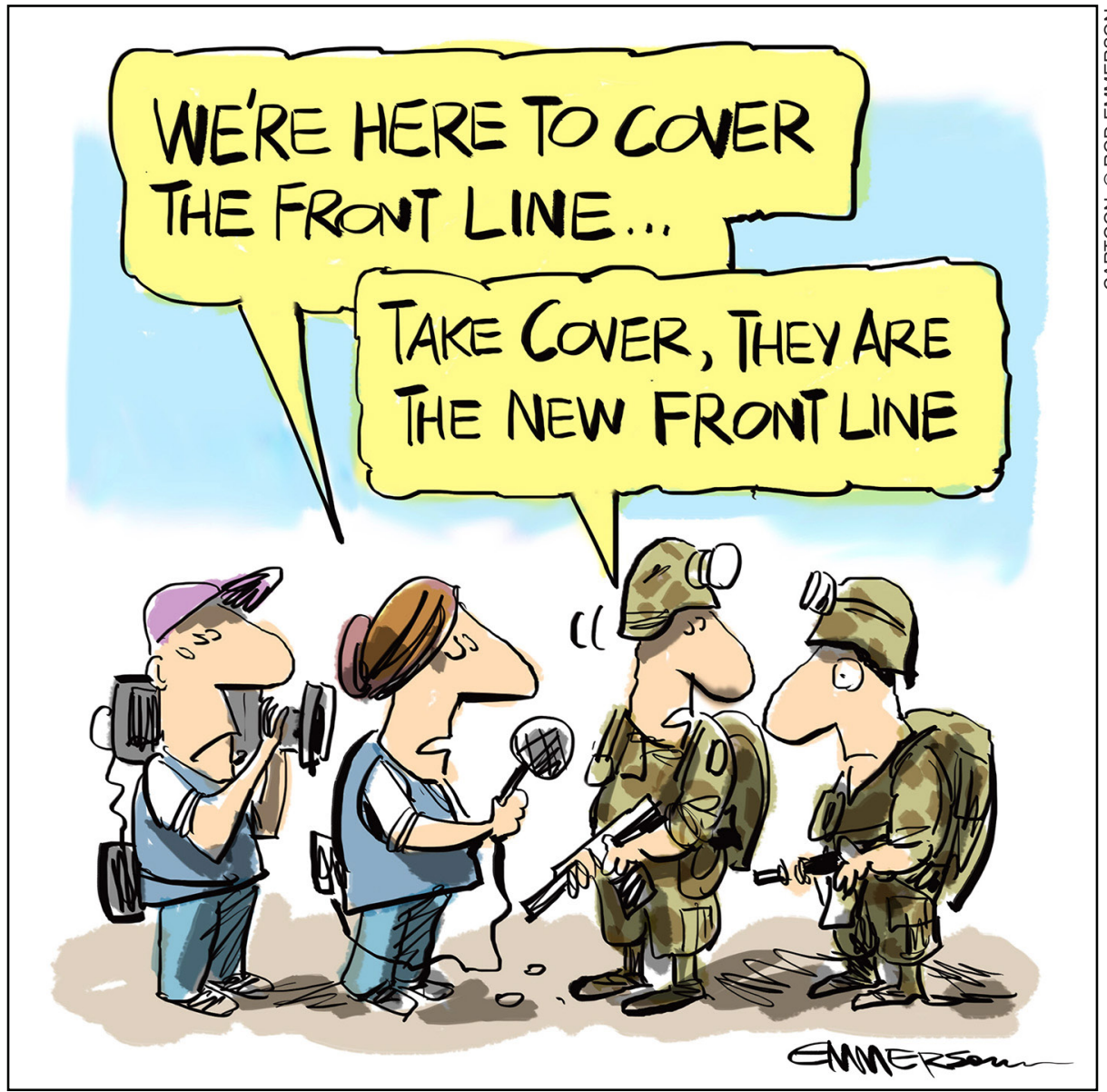

W

ITH the advent of social media, those students who used to disappear from our universities to become bylines in our morning newspapers or pop up on the occasional radio or television news report, are now front and centre in our Facebook feeds each day. There's Bridget, surrounded by soldiers in the Congo (Honan, 2013), less than a year after graduation. There's Manny (Maung \& Winn, 2014), reporting from burnt-out homes in Myanmar. Robbie, barely out of this author's class, filing from Red Shirt protests in Thailand without a helmet, flak jacket, satellite phone or encrypted communication (Baird, 2014). For the past few years, as this author has opened her Facebook news feed, Instagram or Twitter apps, she has had a mounting fear that a former student - encouraged to freelance because of the changing models of journalism-would appear one day in an orange jumpsuit, or worse. Even knowing that good journalism often involves some degree of risk, it is disconcerting for educators in advanced Western countries to think that they have not done 
enough to prepare students for a world where journalists are now being deliberately targeted for political purposes and killed with impunity (Aedy, 2014). It used to be enough for some journalism programmes to prepare students to not lose their minds (Barnes, 2013) to the trauma of reporting. Now we are worried about them losing their lives. As Fairfax photographer Kate Geraghty recalls, how people react to armed conflict is not something that is generally taught:

No one tells you what it's like to, you know, wait for a scud missile to land because there's an air raid going on and to be trapped during a fire-fight. There's no book or movie that can tell you how you're going to feel. (as cited in Anderson \& Trembath 2011, p. 13)

By presenting this paper, the author is not disapproving of such freelance efforts, nor approving of the actions being taken by militant groups to stop journalists from bearing witness to their activities in war zones or other trouble spots. As ABC foreign correspondent Mark Willacy argues, it is important to have Australians in the field:

If Australian reporters aren't on the frontline, who can Australians rely on to tell them the story? CNN? Fox News? Even the BBC's reporting is slanted to suit a British audience. It becomes even more important to have Australian reporters on the ground if there are Australian forces involved in the conflict-which, in the last decade or so, has been the case in every US-led misadventure. (as cited in Anderson \& Trembath 2011, p. 313)

However, this article seeks to consider some of the issues that have arisen around reporting on modern-day conflicts, and calls for better preparation of journalists who freelance and find that they are not being paid enough to acquire the appropriate protective equipment, insurance, training, and post-reporting counselling (e.g., for post-traumatic stress disorder). This author also does not wish to overlook or diminish the vital work of local 'fixers' who sometimes work assisting Western journalists. The Guardian newspaper noted in November 2014 that in the previous 10 months at least 17 Iraqi journalists had been executed by Islamic State (IS) (Henley, 2014). Many others were kidnapped, their fate unknown. The work of these local journalists, who often take the job as fixers for Western reporters, is featured in Murrell's 2011 doctoral thesis, Foreign correspondents and fixers: An investigation of teamwork in international television newsgathering. Murrell acknowledges the vital role fixers play in providing journalists with 'contacts, access, local knowledge, and expert understanding' (Murrell, 2011, p. 243).

In using journalism as a methodology, this article takes its lead from Duffield's (2009) arguments on the distinct advantages of using such a methodology 
in academic research. Duffield (2009, pp. 3-4) suggests that journalism methodology has a number of characteristics, including: observation that is similar to participant observation but not as structured and engaged; empathy between subjects and researchers because of shared professional assumptions and experiences; a strong life knowledge of the researcher about how news is gathered; sense-making of large amounts of information; and, finally, using news values to judge the 'exactitude' of the work under review. This article uses all of these techniques.

\section{Freelancers pay the ultimate price}

There has been growing disquiet about inexperienced freelance reporters and photojournalists turning up with a determination to work in trouble-spots, including war zones. Even before the latest round of high-profile journalist deaths, new minimum standards for journalists working in conflict zones were suggested (Farrell, 2013, p. 27).

When imprisoned in Egypt, Australian journalist Peter Greste-who had been on assignment for Al Jazeera English when he was arrested-raised the issue of freelance work when honouring colleagues Foley and Sotloff, who were both killed by IS in Syria. From prison, Greste wrote: 'Both James and Steven paid the ultimate price for working in an industry increasingly reliant on brave, committed freelancers. They occupied a space where risk-averse news organisations are increasingly outsourcing coverage itself' (Greste, 2014).

War zones are increasingly dangerous places for journalists of any age. British researcher Cristina Archetti found that 40 years ago the average age of a correspondent was 41 and 85 percent were men (Archetti, 2013, p. 424). In the Great War of 1914-1918, two journalists died. In World War II, a total of 69 died. In the Korean War, 17 died. And during the Vietnam War, 58 died (Feinstein \& Sinyor, 2009). In the 2003 invasion of Iraq, 16 Western journalists died in the first two weeks, and, ultimately, more than 200 journalists were killed in that conflict (Feinstein, 2014). In Syria, 94 journalists have been killed since the beginning of the latest conflict (Committee to Protect Journalists, 2016).

The Guardian newspaper's Martin Chulvov noted that the Middle East conflict was being reported on, predominantly, by young people:

For more than three years now, much of what the world has seen, read and learned about the Middle East has been produced by journalism's newest hands. They are not recruits, in the true sense of the word: Few have the endorsement of established media outlets. Even fewer have been sent to the region with budgets, backing, or even basic training. (Chulov, 2014)

Others have noted that even experienced war journalists, such as Marie Colvin - who had spent decades reporting from conflict zones-died because 
of the dangerous and unpredictable nature of civil conflict. Colvin was targeted by the Syrian army in the city of Homs in 2012, dying along with experienced French photographer Remi Ochlik (Borri, 2013). Their deaths sparked a withdrawal of most Western media staff, but not all freelance reporters:

\begin{abstract}
A lightly resourced, laughably paid, almost wholly uninsured cadre of freelancers, often armed with little more than a notebook and a mobile phone, infiltrated Syria anyway. A few were crazy narcissists or war-zone tourists, but most were serious reporters. Four-fifths of all journalists working in Syria, according to one estimate, are freelance and answering to no one but themselves. (Peter, 2014)
\end{abstract}

\title{
Inspiring greatness
}

Journalism educators spend a good deal of time trying to inspire students to greatness; to bear witness, to be like noted foreign correspondents, to shine a light, to live those journalistic clichés that are recognised by most people raised in advanced liberal democracies. Associated Press executive editor Kathleen Carroll puts it in simple terms: 'As long as people are fighting and killing each other, and doing so in the acquisition of power or territory or a point of view, journalists have to be there' (as cited in Al Jazeera, 2014).

In class, educators point to reporters such as Kate Adie, Christine Amanpour, Janine di Giovanni, Zoe Daniel, Eric Campbell, Sally Sara, Mark Willacy, Michael Ware, Debbie Whitmont and Emma Griffiths, among others, who have done extraordinary work. Their work in dangerous places has helped cover and uncover atrocities, spurred governments into action, and given answers to citizens. It has long been seen as difficult work, as veteran Australian reporter Philip Williams wrote after meeting the families from the crash of MH17 in the Ukraine:

It was simply horrific and the act of bearing witness was distressing ... I could give them something they craved-information and a sense of that sad place. I had forgotten the importance of bearing witness. As we left, there were tears and hugs. (Williams, 2014)

Until recent events in Syria, Australian journalists and educators had all but forgotten the Lebanese hostage crisis of the early 1990s, where journalist John McCartney was held hostage for five years before being finally released (McCarthy \& Morrell, 1994). The world was reminded again, after 11 September 2001, about the dangers of journalism when American Daniel Pearl was murdered, prompting the United States to enact the Daniel Pearl Freedom of the Press Act 2009. Australian Michael Ware, a former Time and CNN correspondent, was briefly captured and released by jihadists in 2004 (Anderson $\&$ Trembath 2011, p. 15). However, after more than 10 years with few horrific 
headlines - for Western journalists, at least - those who gather and report the news are again being used as 'targets, or commodities to be traded for ransom' (Leridon, 2014).

\section{Journalists have become the target}

Journalists are no longer considered observers of the story. In some cases, they have become the story. The change was first noted after the 1992-95 Bosnian war (di Giovanni, 2014), but really came into focus after 11 September 2001, according to Canadian psychiatry professor Anthony Feinstein:

It took the kidnapping of the Wall Street Journal reporter Daniel Pearl and his subsequent beheading to put journalists on notice that they, too, were now firmly in the cross-hairs of insurgents, militants, terrorists, thugs, call them what you will according to your level of political sensitivity. (Feinstein, 2014)

While in jail in Egypt, Greste noted that recent conflicts in the Middle Eastparticularly those since the Arab Spring - have put journalists squarely in the sights of combatants in a way he had not seen before: 'Of course propaganda is as old as war itself, and warring factions have always sought to control the narrative of a conflict. But, in these wars over stuff, the target has generally been the message rather than the messenger' (Greste, 2014).

Another Al Jazeera journalist, Kimberley Dozier, suggested that those in the field were well aware that the word 'press' put them in the firing line:

To them, I'm a Western with a potential price tag on my head. When we help someone who had no way of reaching the levers of power, that's what the Fourth Estate is all about. That's why I'm risking my life. If you want to get to some of these stories, then you have to take the risks that are being faced by the people living through these things. Sometimes that means risking torture, risking kidnapping, risking death. (as cited in $\mathrm{Al}$ Jazeera, 2014)

American reporter Jeffery Goldberg was even more candid:

Western journalists who seek out jihadists are courting death. The extremists don't need us anymore. Fourteen years ago, while I was staying at the Taliban madrasa, its administrators were launching a web site. I remember being amused by this. I shouldn't have been. There is no need for a middleman now. Journalists have been replaced by YouTube and Twitter. And when there is no need for us, we become targets. (Goldberg, 2014) 


\section{Mental preparedness}

Most Australian universities use the resources of the Dart Asia Pacific Center for Journalism and Trauma (Dart Center for Journalism and Trauma, 2014), and Mindframe (Mindframe National Media Initiative, 2014), to warn that reporting from conflict zones is both important and mentally challenging. As former $\mathrm{ABC}$ foreign correspondent Sally Sara wrote of her own experience of posttraumatic stress disorder:

One of the big misconceptions is that PTSD is all about the blood and bullets and the bombs and the fear. But, for many people, it's more complicated than that. Mental health experts use a term called moral injury. That means that what you saw was not just physically confronting, but it was wrong, morally wrong. (Sara, 2014)

The resources from the Dart Center and Mindframe focus on students' and journalists' mental preparedness, rather than on physical preparedness or risk assessment. How many courses actually prepare students to take care of themselves physically? Do educators give them the skills to make a proper risk assessment? Do they make sure they understand the differing rules of engagement from place to place? Or are educators so busy trying to ensure students are skilled to work as freelance operatives, that they forget they are preparing tomorrow's journalists for an increasingly physically dangerous world where reporting the news, particularly for young women, can put their lives on the line? News organisations, including the Australian Broadcasting Corporation, use hostile environments training organisation such as Dynamiq or the AKE Group, but these are rarely accessible to, or affordable by, young freelance journalists.

\section{The blood, and the bang bang}

This article recognises that Western news values create an insatiable thirst for dramatic stories and vision that can encourage freelance journalists to take inappropriate risks in order to 'get the story' or 'grab the money shot'. Sometimes this goes beyond encouragement to do dangerous stories, as Italian journalist Francesca Io explained:

Editors back in Italy only ask us for the blood, the bang-bang. I write about the Islamists and their network of social services, the roots of their power - a piece that is definitely more complex to build than a frontline piece. I strive to explain, not just to move, to touch, and I am answered with: 'What's this? Six thousand words and nobody died?' (as cited in Borri, 2013)

The United Nations security council has strengthened the laws governing the protection of journalists, and the UN General Assembly moved in 2014 to ratify 
new laws to further protect journalists (United Nations, 2013). But it does not matter how many times you tell a young journalist that you cannot file if you are dead, there will always be other players urging them on:

There was a tension between the safety of reporters and their desire to meet editors's needs to gain dramatic vision of disasters, from riots to bushfire. Editors, in turn, were aiming, perhaps not quite consciously, to satisfy audience desires both for information and for schadenfreude. This German word, with no direct equivalent in English, describes a kind of pleasure or satisfaction felt at someone else's misfortune which might be a contributor to the popularity of disaster footage. (McLean \& Power, 2013, p. 14)

Borri noted there were few financial rewards for doing life-threatening journalism, and the poor pay encouraged freelancers to take inappropriate risks:

... whether you're writing from Aleppo or Gaza or Rome, the editors see no difference. You are paid the same: $\$ 70$ per piece. Even in places like Syria, where prices triple because of rampant speculation. So, for example, sleeping in this rebel base, under mortar fire, on a mattress on the ground, with yellow water that gave me typhoid, costs $\$ 50$ per night; a car costs $\$ 250$ per day. So you end up maximizing, rather than minimizing, the risks. Not only can you not afford insurance — it's almost $\$ 1000$ a month — but you cannot afford a fixer or a translator. You find yourself alone in the unknown. The editors are well aware that $\$ 70$-a-piece pushes you to save on everything. They know, too, that if you happen to be seriously wounded, there is a temptation to hope not to survive, because you cannot afford to be wounded. But they buy your article anyway, even if they would never buy the Nike soccer ball handmade by a Pakistani child. (Borri, 2013)

\section{'Don't shoot: we're from Channel Nine'}

This author's unease with the preparation of students started long before Foley's death hit front pages and television screens (Chulov, 2014). It's something that this author has talked to students about since the 2009 film Balibo was released. It is hard not to be struck by the movie's dramatisation of the moments before the group of five Australian and British journalists were killed on 16 October 1975. In that moment - and, of course, the precise truth of what happened is unclear-one of the journalists, who had been sheltering in a house with a painting on its wall of a large Australian flag, put his hands in the air and shouted 'Don't shoot, we're from Channel Nine', or words to that effect. The call was ignored, and the journalists killed. It is footage played to students in their broadcast journalism classes, and this author always asks: 'What is it that makes journalists think that they will not be targeted?' Usually, students say, because the targets are journalists, killing them would cause the perpetrators 
greater trouble than letting them go. As the Balibo Five families know, this is not necessarily the case. There still has been no one held to account for those deaths and the Australian Federal Police investigation of the matter was abandoned in 2014 (MEAA, 2014).

The difference between the Balibo Five and many young journalists who head out to gather global news today is that most of the Balibo Five were employees. To some extent, they also had others-albeit in another country-looking over their shoulders and trying to keep them safe. However, freelance journalists, particularly young ones without an extensive network of contacts, are unlikely to have a foreign editor yelling at them to get themselves out of there, now. With the courage and idealism of youth, instead they book a flight to somewhere dangerous, take out their iPhones, and start filing for anyone who will pay (Hyland, 2012). It proves an addictive adrenaline rush.

Educators need to make sure students are prepared physically as well as mentally. For that, students can get training from the International Federation of Journalists or tap into the online safety resources of the Committee to Protect Journalists and the International News Safety Initiative. There are no guarantees, though, as a convoy of journalists discovered in the Philippines in 2009 (Hodal, 2012). Even though they were traveling in a large group, it did not stop 32 journalists from being executed in a pre-meditated political massacre (Pollard, 2009).

Educators also need to warn female journalists that they face added danger when travelling and reporting in some countries. The International News Safety Institute is among those bodies that have created a special safety advisory for female journalists (International News Safety Institute, 2014). Figures on sexual violence against women in Egypt, for example, are particularly frightening. Egyptian journalist Nadine Marroushi wrote of the situation in Cairo's Tahir Square in 2013:

On 25 January, at least 25 women were sexually assaulted and in some cases raped with sharp objects by mobs of men. There have been at least 500 survivors of sexual violence crimes in Egypt between February 2011 and January 2014. (Marroushi, 2014)

This danger was earlier underscored by the mob rape of US CBS correspondent Lara Logan in Tahir Square in Egypt in 2011. Logan thought she was going to die the night Hosni Mubarak's government fell in Cairo in February 2011. She was in the square preparing a report for 60 Minutes when the crowd's celebratory mood turned threatening and she was dragged away from her producer and bodyguard by a group of men. They tore her clothes off and raped her with their hands for an extended period of time - a 'brutal and sustained sexual assault and beating' - an attack involving 200 to 300 men (Stelter, 2011). In the weeks following Logan's assault, other women recounted being harassed and 
assaulted while working overseas, and groups like the Committee to Protect Journalists said they would revise their handbooks to better address sexual assault.

\section{Embed yourself}

Educators could encourage students to consider embedding themselves with a defence force or perhaps even a non-government organisation (NGO). Acknowledging, of course, that being embedded will impact on their perception of the stories they produce. Some of Australia's top journalists - such as Walkley Award-winning reporter Chris Masters, Geoff Thompson, Michael Cox, Michael Ware and Lindsay Murdoch - have embedded with the Australian military (Anderson \& Trembath, 2011, p. 360). The ABC's Tony Hill suggested embedding was useful for 'safety, physical access, the clones of combat and the proximity to spokespeople and the military' and the Nine Network noted that it was valuable to be able to 'interact with the troops and gain information which differed from the official briefings' (Anderson \& Trembath, 2011, p. 359). Australian reporters Trevor Bormann, Kate Geraghty, Mark Willacy and Louie Eroglu can all bear witness to the dangers faced by journalists not under the control of the military (Anderson \& Trembath, 2011, p. 371).

Educators also need to talk to students about the value - and danger-of embedding with the 'enemy', as VICE News reporter Medyan Dairieh did for his 2014 documentary, The Islamic State. Elsewhere, captured journalist John Cantlie was presumably forced to host videos for IS from Kobani on the SyriaTurkey border, where he was videoed by IS, stating:

Now, I know what you're thinking. You're thinking: 'He's only doing this because he's a prisoner, he's got a gun at his head and he's being forced to do this.' Right? Well it's true. I am a prisoner. That I cannot deny. (as cited in Barry, 2014)

It is also worth revisiting the work of Wilfred Burchett, the Australian journalist known for his reporting of conflicts in Asia and his Communist sympathies (Bradbury \& Young, 1981). Burchett and The Age photographer Hugh Bull were the first journalists to enter Hiroshima after the atomic bomb was dropped. Burchett later attracted controversy for reporting behind enemy lines during the Korean and Vietnam Wars. New Zealand academic David Robie described Burchett as 'one of the most courageous journalists' he had met, but noted that he was 'loathed by many of his countrymen who regarded him as public enemy number one because they believed he was a traitor' (Robie 2014, p. 21). Robie had been editor of the Melbourne Sunday Observer whose chief correspondent was Burchett and which hired an aircraft in 1970 to fly him back to Australia from Noumea to regain his Australian passport. 
Veteran $\mathrm{ABC}$ correspondent Peter Cave, however, warned against embedding with armies that he thought 'were breaking international law or committing atrocities' (Anderson \& Trembath 2011, p. 359). The reality in Syria in 2013-14 was also difficult, as Borri noted:

We are squeezed between a regime that grants you a visa only if you are against the rebels, and rebels who, if you are with them, allow you to see only what they want you to see. The truth is, we are failure. (Borri 2013)

\section{Lesson one-know your employer}

The changing media landscape has made a huge difference to the employment prospects of young journalists (Rottwilm, 2014). Not only is there a greater demand for instantaneous news, there are also fewer newspapers, fewer foreign bureaux and greater editorial control. There is also a greater reliance on syndicated news and work from freelance journalists. Even the Australian Broadcasting Corporation, once considered a leading example for international reporting, has had to cut its number of overseas offices and staff (Meade, 2010a). Murrell (2014, p. 17) notes that freelance journalists often believe that, if they work in conflict zones, it will help 'parlay their experience into more permanent work with media organisations'. Using Bourdieu's idea of cultural capital, Murrell (2014) notes that the 'B-team' - usually freelance journalists- have less cultural capital than staff members and have to 'hustle and live on their wits'.

Those who are employed by large media outlets such as the Australian Broadcasting Corporation or Fairfax will find that the duty of care extended to employees will keep them a little safer-news managers are unlikely to approve seriously dangerous work and, if they believe their staff are in danger, they will recall them. The former editor-in-chief of The Age, Andrew Holden, was quoted, saying: 'All correspondents going into a war zone must file a security plan before they leave, which is assessed by an international security expert, and on this person's recommendations we either approve or disapprove' (as cited in Garg \& Mann, 2014).

There is a growing appreciation of the dangers faced by freelance journalists among the major news outlets. ABC (America) recently recalled a freelance cameraman who contracted Ebola (Besser, Leong, \& Candea, 2014) while working for them and Reuters, too, has a proactive approach to its freelance journalists. But news outlets are not all equally supportive of freelance personnel. Greste discovered an initial lack of support from Al Jazeera English after he and two colleagues were detained in Cairo on 29 December 2013 and charged with spreading 'false news'. Although Al Jazeera English claims editorial independence, the local Egyptian Al Jazeera channel, Mubasher Misr, had taken a political stance (Verbossen, 2014, p. 8) and was the subject of a legal battle with the Egyptian 
government at the same time as Greste and his colleagues were fighting a court case (Peter Greste Trial, 2014).

While few major news outlets are prepared to let staff members work inside dangerous countries, some are prepared to commission freelance journalists to do the work, even though it is inherently dangerous. In 2011, Libya was considered a 'buyers' market' for freelance journalists, where many worked with 'no insurance, no expenses, or even airfares to get them home again' (Chulov, 2014). Of 72 journalists killed in Syria since the outbreak of the latest conflict in 2014 (Committee to Protect Journalists, 2014), 27 were freelance reporters and photographers, but only three were employed by news organisations based outside the Middle East. In a report for the Samir Kassir Foundation, security risk analyst and freelance journalist Shane Farrell (2013) reported a massive increase in the number of freelance journalists killed since the Committee to Protect Journalists began collecting data in 1992.

Some news agencies and outlets, such as Agence France-Presse (AFP) and The Sunday Times (Taibi, 2014), have decided to no longer accept freelance reports from Syria because of the danger to freelance reporters. AFP hopes the ban on images and information from freelance operators in Syria will not encourage journalists to take risks which could lead to them to 'being used as a vehicle for hateful, ultra-violent propaganda' (as cited in Taibi, 2014). It is important to note that journalists killed in Syria had also undergone other abuses. At least four who were held hostage by IS were waterboarded before being murdered (Goldman \& Tate, 2014).

Not all organisations are refusing to accept freelance work from Syria. In late 2014, the Melbourne-based Newsmodo content marketing agency was still encouraging freelance journalists to file on IS for Australian news outlets in its invitation to 'pitch to this brief':

information on these (ISIS) terrorists, including exclusive interviews with either them, their families or people who know them well. What motivated them to join ISIS? What are they hoping to achieve? What is their background? Both video and print submissions will be accepted. (Newsmodo, 2014)

The UK-based Rory Peck Trust-which was set up to honour the freelance cameraman killed in Russia in 1993 - urges freelance journalists to attend a five-day hostile environment course, and to learn not to accept assignments without checking where they stand with those commissioning their work. The trust's head of communication, Molly Clarke, suggests asking editors a number of questions: 'Is there a protocol if something is to happen to me? Would I be covered by insurance? Do you have a communications plan? Do you provide 
cash up front? Will you help organise my travel, fixers, drivers, etc.?' (as cited in Weiss, 2013).

\section{Lesson two - learn the local code (understand difference)}

Journalists from advanced liberal democracies such as Australia are enculturated to believe everyone everywhere should expect to enjoy the same foundations of individual liberty that Australians have: relatively free speech, self-determination, property rights, as well as freedom of association, worship and movement. Freedom of speech, and by extension the freedom to report, is thought to be a concern for 'everyone'.

This article argues that it is important that journalists working outside their own lands acknowledge, before they start work, that they will hold normative Western journalistic views. According to Schultz (2007), culturally specific journalistic habitus:

implies understanding the journalistic game from a Western liberal point of view, and being able to master the rules of that same game. But the game can be played from different positions, and different dispositions point to different forms of mastering the game. (Schultz, 2007, p. 193)

The superiority of the Western journalistic model has taken on almost mythic proportions. Veteran Australian current affairs journalist and foreign correspondent Peter Lloyd articulated this deep-held belief:

I've spent too many years living in, working in, and reporting on broken and rorted countries not to learn this: The common denominator is a weak media sector. All of us keep the bastards honest, and beware the politician. Every one of them benefits when we lose a second on air, or a soldier in the trench. This is not (a) career; it is a vocation, and it's time the army spoke out. (as cited in Knott, 2014)

Journalists working internationally may enter a country understanding from the 'journalist habitus' who the good guy is and who the bad guys are, but once on the ground it may seem very different. As Chulov noted of his experience in Libya: 'The good guy/bad guy narrative that appeared clear-cut at the start, drifted steadily to uncertainty. Difficult, important decisions needed to be made about who to trust and when to cut and run' (Chulov, 2014).

Greste addressed this issue in a speech, saying Western ideals of neutral and independent reporting were gone:

Journalists are no longer on the front lines. We are the front lines. In this wider conflict, there is no such thing as a neutral, independent reporter. In the view of both sides, if you cross the lines in pursuit of our most funda- 
mental principles of balance, fairness and accuracy, you effectively join the enemy. The compelling world views seem so widely divergent that to even try to understand the other side is to commit what many governments now consider to be treason. (Greste, 2014)

Farrell also noted the need for ethical and fair journalists, suggesting that freelance operators were 'ambassadors for their profession': 'Malpractice by one individual - whether willingly or through ignorance - can taint the reputation of all journalists, making newsgathering more difficult the longer the conflict lasts' (Farrell, 2013, p. 16).

Greste (2014) suggested that journalists could not rely on the public to support them in their role, even if they wanted reliable news. He suggested that, regardless, it was important to improve professional standards:

Our best strategy as an industry starts with a rock-solid commitment to our core ethical and professional standards. The more sloppy we get, the more we degrade public support for our business, the more excuses we give to governments to limit and control what we do. (Greste, 2014)

The call to improve global journalism is hardly new, but was particularly fervent in the period after 9/11, the 2001 Afghanistan war, and the 2003 Iraq war. German scholar Kai Hafez argued that those conflicts showed how the world's journalists framed the story on 'home-grown narratives' (Hafez, 2009):

Western media cover the country through the lens of the nuclear issue,
Muslim veiling and Ahmadinejad. The enormous paradoxes of the country
go unnoticed. Columbus thought he had reached India when he had, in
fact, discovered America. But are we today really that much further than
Columbus was? (Hafez 2009, p. 330)

Hafez argues - as Daniel Hallin (1986) did with his study of the coverage of the Vietnam War - that there is a susceptibility of journalism cultures to 'patriotic, ethnocentric and other biases' which are related to world-views of audiences, 'which are themselves partly the product of the international patchwork journalism of modern mainstream media' (Hafez, 2009, p. 330).

Hafez (2009) puts the blame for poor global journalism on a lack of international education among most journalists, language hurdles, shrinking networks of foreign correspondents, public relations and propaganda being peddled through newsrooms, and the dependence of the media on domestic markets:

Despite telling Western audiences that the Middle East is simply conflicdriven, the USA [is] an imperialist monolith or China 'the next superpower', we must try [to] understand the complexities of such world regions, their 
multiple histories and current often paradoxical developments. We must try [to] understand each other-just like in a real village. (Hafez, 2009, p. 331)

Farrell (2013) suggests language skills, even basic ones, could help get someone out of trouble, and that an understanding of and empathy with religious issues could be vital. Writing before more recent IS attacks on Western journalists, Farrell (2013, p. 12) observed how a knowledge of the fundamentals of Islam in Muslim-majority countries could save someone's life. He drew on the experiences of a Médecins Sans Frontières (MSF) staff member who was kidnapped by Islamist militants in Chechnya and saved her own life by singing the call to prayer just before she was to be shot (Garthwaite, 2001, p. 34).

\section{Lesson three - learn risk assessment}

This article argues that it is essential to teach student journalists how to do a risk assessment, or at least direct them to where they can learn about risk assessment. It could be worthwhile for Australian educators to look to the experience of educators in Fiji and Papua New Guinea who have found that their students have sometimes faced direct action or threats over stories they have prepared as part of their classes. Pacific academic David Robie advocates what he calls 'critical development journalism' and suggests that, instead of teaching normative Western journalism skills alone, that students be taught how to report on what may be considered blasphemy, sedition and treason as well as and how to deal with physical threats and bribery (Robie, 2014, p. 344).

One of the most important lessons to teach is that journalists have increasingly become hunted as targets (Borri, 2013). And being an Australian does nothing to mitigate that risk. $\mathrm{ABC}$ correspondent Trevor Bormann noted that the attitude to Australia changed after the first Iraq war:

Once upon a time, if you were an Australian journalist abroad you could bank on the fact that you were from a fairly obscure country ... The perception was that it was fairly innocuous, fairly neutral in any conflict. But now that's changed ... every single Iraqi I met knew that Australia was part of the coalition, so because of that they questioned whether you were there to enhance the Australian war effort. (as cited in Anderson \& Trembath, 2011)

This has only been exacerbated more recently with IS extremists specifically naming Australia, and former Prime Minister Tony Abbott, in its propaganda (Wroe, 2014). While hostile environment training is now mandatory for permanently employed foreign correspondents (Garg \& Mann, 2014), many news organisations now require freelancers to complete hostile environment training before they will commission a reporter, and so it is useful to have safety training before freelance journalists pitch a project. 
There are Australian-based training companies that prepare journalists from Australia's major media outlets: RedR, Cavell Group, Dynamic Alternatives Group, BLP Training and Services, and Betlin. Betlin does not currently appear to be active online, however one of their graduates, The Age's Jewel Topsfield, said:

The best thing about this training is it is conducted by ex-military people who teach journalists how to plan... Journalists are used to responding to deadlines, so they wing things. The training teaches basic first aid, including bullet wound management and has simulation sessions that can be intimidating initially. (Garg \& Mann, 2014)

In the United Kingdom, the Rory Peck Trust also organises training and, in 2013, offered 38 bursaries to freelance journalists from Europe, the US and the Middle East to attend its five-day hostile environment course (Rory Peck Trust, 2013 , p. 48). There are a range of international organisations that can also help with risk assessment, such as the US-based Committee to Protect Journalists, which urges journalists to consider the normal risk assessments of battlefield hazards and abductions for political gain. It urges journalists to:

be in regular contact with an editor, colleague, family member, or other reliable person ... Most important, you and the contact person must decide in advance at exactly what point a failure to check in is considered an emergency and whom to call for a comprehensive response in locating you and securing your exit or release. The response often entails systematically reaching out to colleagues and friends who can assess the situation, to authorities who can investigate, and to the diplomatic community to provide potential support and leverage. (Committee to Protect Journalists, 2014)

Many experienced foreign correspondents are also keen to share their knowledge. The Times' correspondent Iona Craig wrote of the need for journalists to return to old-school methods of communication to ensure their safety in conflict zones or to use encrypted methods of email, telephony or social media: 'What should not be forgotten when working in conflict zones is that the hidden threat of government surveillance is as real as the visible one from bombs and bullets' (Craig, 2014, p. 12).

The Rory Peck Trust also urges journalists to complete a risk assessment before they begin a project, to help "manage and minimise risks, be better prepared before an assignment and able to respond to an emergency on location" (Rory Peck Trust, 2014). Feinstein (2014) makes the point that journalists are unlike other people in war zones - they are not schooled in violence. There is no training programme to truly prepare them for the front lines:

Transplanted overnight from the safety of a desk job back home to a bureau under threat in a country where security is tenuous or absent, the 
language incomprehensible, the heat sapping and the local government, if still functioning, hostile to a free press, journalists must learn on the go, in haste and with little room for error, because in war zones, survival is often measured in milliseconds or millimetres. (Feinstein, 2014)

\section{Conclusion}

This article has argued that changing employment conditions for young, mostly freelance journalists have put greater pressure on journalism educators to ensure students are better prepared for freelancing. While this article has looked at events in the Middle East, much closer to home journalists are being jailed as well, as two experienced French journalists found out when they attempted to illegally report in Indonesia's Papua province (Agence France-Presse, 2014).

This article suggests journalism educators should ensure that $j$-school graduates recognise three lessons:

1. That they know the dangers of working for various employers when freelancing;

2. That they understand that the professional and cultural norms of advanced Western nations may not be observed in the countries from which they are reporting;

3. That they know of the need to understand risk assessment, which includes pre-deployment training in first aid, personal safety, security and other protocols and managing exposure to traumatic situations.

While these three lessons may discourage young people from reporting internationally, the stories still need to be told. Agence France-Presse agrees that, while there is no easy answer to reporting the events in Syria, it is important that a balance be struck between: '.. our duty to inform the public, the need to keep our reporters safe, our concern for the dignity of victims being paraded by extremists, and the need to avoid being used as a vehicle for hateful, ultraviolent propaganda' (Leridon, 2014).

Leridon (2014) says that the AFP suggests that it is possible in other war zones - such as the Ukraine, Gaza and the Central African Republic - to continue to report because there are usually safe havens in war zones where journalists can work and file stories and get some rest. The same, however, cannot be said for Syria where the country is now seen as being 'dangerous from one end to the other' (Leridon, 2014).

Farrell also makes a strong argument in support of journalistic work from conflict zones, stating that its role in serving the public interest is often overlooked because of more commercial, 'trivial' news:

War reporters often lay the foundations for how history will be written and events remembered. At the best of times, war correspondents have had a positive impact on policy decisions and provided witness accounts 
for criminal proceedings; crimes for which the perpetrators would never have been brought to justice otherwise. Such reporting helps cut through opposing, often propagandistic, narratives and present facts as they really are. It is in society's interest to maintain the quality of journalism, and, by extension, it is in society's interest to have minimum working standards for all journalists working in conflict zones. (Farrell, 2013, p. 27)

There does not appear to be great public support for the work of war correspondents, nor consciousness of their problems or concerns, nor - as US journalist Nicholas Kristof wrote in 2014-about the brevity of coverage being given, despite strong public pressure for more news on ongoing conflicts:

So far this year, nightly newscasts on ABC, CBS and NBC have offered a combined total of 3 minutes of coverage of the civil war and impending famine in South Sudan, and 9 minutes about mass atrocities in the Central African Republic, according to Andrew Tyndall of the Tyndall Report, which tracks such things. In contrast, the missing Malaysian airliner drew 304 minutes (almost five times as much as the Syrian civil war) (Kristof, 2014).

Goldberg said he used to be sought out by young people wanting a career in the Middle East. He recently changed his advice:

I would tell them that this was an excellent idea: save some money, go learn Arabic, be a newspaper stringer, grab for the big stories, and you'll have an interesting life. Steven Sotloff was one of those who sought my advice. His Middle East career was already under way (he was living in Israel at the time), and I prefer to think that he could not have been dissuaded. But I'm capable of learning, and my advice now is to go somewhere else. (Goldberg, 2014)

\section{References}

Aedy, R. (2014, October 30). Protecting photographers [Online media report]. $A B C$ Media Report, 30 October. Retrieved from www.abc.net.au/radionational/programs/ mediareport/protecting-photographers/5854682

Agence France-Presse. (2014, October 24). French journalists handed short jail terms in Papua, to walk free. Jakarta Globe. Retrieved from http://jakartaglobe.beritasatu. com/news/french-journalists-handed-short-jail-terms-papua-walk-free/

Al Jazeera journalist found guilty, sentenced to seven years in jail. (2014, June 24). $A B C$ Online. Retrieved from www.abc.net.au/news/2014-06-23/peter-greste-jailedin-egypt/5543292. Al Jazeera. (2014, July 15). Killing the messenger [Video file]. Retrieved from www.aljazeera.com/programmes/specialseries/2014/07/killingmessenger-201478101852958418.html 
Anderson, F., \& Trembath, R. (2011). Witness to war: The history of Australian conflict reporting. Carlton, Vic: Melbourne University Publishing..

Archetti, C. (2013). Journalism in the age of global media: The evolving practices of foreign correspondents in London. Journalism, 14(3), 419-36. doi: $10.1177 / 1464884912472140$

Baird, R. (2014, June 6). Chiang Mai dissents face uncertain future after Thai coup. The World..Retrieved from http://www.abc.net.au/news/2014-06-06/chiang-maidissidents-face-uncertain-future-after/5507364

Barnes, L. (2013). A trauma shake-up: Are NZ graduates being prepared for the real world? Pacific Journalism Review, 19(1), 282-9. Retrieved from http://search.informit. com.au/documentSummary; $\mathrm{dn}=336681713679292 ;$ res=IELHSS

Barry, P. (2014, November 3). New frontier in the propaganda war. ABC Media Watch [Video file \& transcript]. Retrieved from www.abc.net.au/mediawatch/transcripts/ s4120792.htm

Besser, R., Leong, J., \& Candea, B. (2014, October 2). Doctors 'optimistic' about prognosis for American journalist with ebola, family says. $A B C$ News. Retrieved from http://abcnews.go.com/Health/family-identifies-american-journalist-tested-positiveebola/story?id $=25930807$

Borri, F. (2013, July 1). Woman's work: The twisted reality of an Italian freelancer in Syria. Columbia Journalism Review. Retrieved from www.cjr.org/feature/womans_work.php?page $=$ all

Bradbüry, D. (Director), \& Young, S. (Co-Director?). (1981). Public enemy number one [motion picture]. Location: Frontline Films.

Chulov, M. (2014, August 22). James Foley and fellow freelancers: Exploited by pared back media outlets. The Guardian Retrieved from www.theguardian.com/media/2014/ aug/21/james-foley-freelance-journalists-exploited-media-outlets

Committee to Protect Journalists. (ca. 2014, 2016). Journalists killed in Syria since 1992/ motive confirmed. Retrieved from https://cpj.org/killed/mideast/syria

Craig, I. (2014). Back to the future: Trying to stay safe in war zones. Index on Censorship, 43(3), 8-12. doi: 10.1177/0306422014548392

Dairieh, M. (ca. 2014). The Islamic State. VICE News [Video file]. Retrieved from https:// news.vice.com/show/the-islamic-state

Dart Center for Journalism and Trauma. (2014). Self care [tip sheet]. Retrieved from http://dartcenter.org/topic/self-care

di Giovanni, J. (2014, September 29). Remembering Steve Sotloff, and too many others. Newsweek. Retrieved from www.newsweek.com/remembering-steve-sotloff-and-toomany-others-268043

Duffield, L.R. (2009). A news story as big as a doctoral thesis? Deploying journalistic methodology in academic research. Paper presented at the Communication, Creativity and Global Citizenship Conference. Retrieved from http://eprints.qut.edu. au/28886/1/28886.pdf

Farrell, S. (2013, August 30). Journalists' security in war zones: Lessons from Syria, Samir Kassir Foundation Centre for Media and Cultural Freedom. SKeyes. Retrieved from www.skeyesmedia.org/extensions/pdf/Journalists\%5C\%27_Security_in_Conflict_Zones-SKeyes\%5B3\%5D.pdf

Feinstein, A. (2014, August 29). In harm's way: Why war correspondents take risks and how they cope. The Globe and Mail. Retrieved from www.theglobeandmail.com/ news/world/in-harms-way-why-war-correspondents-take-the-risk/article20278510/

Feinstein, A., \& Sinyor, M. (2009, December 11). Women war correspondents: They are 
different in so many ways. Nieman Reports. Retrieved from http://niemanreports.org/ articles/women-war-correspondents-they-are-different-in-so-many-ways/

Garg, K., \& Mann, S. (2014, November 5). Protecting the messengers: news groups rethink safety for correspondents on the frontline ... and at home. The Citizen. Retrieved from www.thecitizen.org.au/features/protecting-messengers-news-groupsrethink-safety-correspondents-frontline-and-home

Garthwaite, R. (2011). How to avoid being killed in a war zone. London: Bloomsbury.

Goldberg, J. (2014, December). Before the beheadings. The Atlantic. Retrieved from www.theatlantic.com/magazine/archive/2014/12/before-the-beheadings/382244/

Goldman, A., \& Tate, J. (2014, August 28). Captives held by Islamic State were waterboarded. The Washington Post. Retrieved from www.washingtonpost.com/world/nationalsecurity/captives-held-by-islamic-state-were-waterboarded/2014/08/28/2b4e19622ec9-11e4-9b98-848790384093 story.html

Greste, P. (2014, October 20). Peter Greste speaks on the war on terror from prison. The Australian. Retrieved from www.theaustralian.com.au/business/media/peter-greste-speaksof-the-war-on-terror-from-prison/news-story/f740b68a2d4ee1f77flaa55d75b9838b

Hafez, K. (2009). Let's improve 'global journalism'!. Journalism, 10(3), 329-31. doi: $10.1177 / 1464884909102576$

Hallin, D. (1986). The uncensored war: The media and Vietnam. New York: Oxford University Press.

Henley, J. (2014, October 20). Victims of Isis: non-Western journalists who don't make the headlines. The Guardian.. Retrieved from www.theguardian.com/world/ shortcuts/2014/oct/19/victims-of-isis-non-western-journalists-dont-make-headlines

Hodal, K. (2012, November 23). Philippines massacre: Three years on, victims' families still waiting for justice. The Guardian. Retrieved from www.theguardian.com/ world/2012/nov/22/philippines-massacre-families-waiting-justice

Honan, B. (2013, December 4). And this is too hard; on life and early death in the Congo [blog post].Retrieved from www.bridget.com.au/2013/12/04/and-this-is-too-hard-onlife-and-early-death-in-the-congo

Hyland, T. (2012, February 19). Postcards from the edge: the tourist journalists who pack thier iPhones and head to war. The Sunday Age. Retrieved from www.theage. com.au/frontpage/2012/02/19/frontpage.pdf

International News Safety Institute, 2014 [Ref details missing]

Knott, M. (2014, September 28). ABC stars unite to save Lateline from the axe. Sydney Morning Herald. Retrieved from www.smh.com.au/federal-politics/political-news/ abc-stars-unite-to-save-lateline-from-the-axe-20140928-10n9sh.html

Kristof, N. (2014, September 3). When reporting is dangerous: Steven Sotloff and James Foley elevated journalism and society. The New York Times. Retrieved from www. nytimes.com/2014/09/04/opinion/when-reporting-is-dangerous.html? r $=0$

Leridon, M. (2014, September 17). Covering the 'Islamic State' AFP [b- og post]. Retrieved from http://blogs.afp.com/correspondent/?post/covering-the-islamic-state-afp

Marroushi, N. (2014, September 4). Breaking the taboo: 'I reported from conflict zones and got post-traumatic stress disorder'. The Telegraph. Retrieved from www.telegraph. co.uk/women/womens-life/11074792/Isil-beheading-of-Steven-Sotloff-I-reportedfrom-conflict-zones-and-got-post-traumatic-stress-disorder.html

Maung, M., \& Winn, P. (2014, May 7). How Myanmar's government is making violence between Muslims and Buddhists worse, Global Post. Retrieved from www.globalpost. com/dispatch/news/regions/asia-pacific/myanmar/140506/Wirathu-Meikhtila-MuslimBuddhist-killing-Myanmar-reconstruction 
McCarthy, J., \& Morrell, J. (1994). Some other rainbow. London: Bantam Press.

McLean, H., \& Power, M.R. (2013). When minutes count: Tension and trust in the relationship between emergency managers and the media. Journalism, 15(3), 307-325. doi: $10.1177 / 1464884913480873$

MEAA (Media Entertainment and Arts Alliance). (ca. 2014). AFP fails the Balibo Five, impunity wins. Retrieved from www.alliance.org.au/oldsite/afp-fails-the-balibo-fiveimpunity-wins

Meade, A. (2010a, November 2). ABC cuts infuriate overseas reporters. The Australian. Retrieved from www.theaustralian.com.au/business/media/abc-cuts-infuriateoverseas-reporters/story-e6frg996-1225946346432

Mindframe National Media Initative. (2014). Mindframe for journalism and public relations [educational booklets]. Retrieved from http://www.mindframe-media. info/_data/assets/pdf_file/0017/5273/Journalism-Fact-or-Fiction.pdf AND http:// www.mindframe-media.info/_data/assets/pdf_file/0008/5894/Issues-and-Impact.pdf

Murrell, C. (2011). Foreign correspondents and fixers: An investigation of teamwork in international television newsgathering. Unpublished doctoral dissertation, The University of Melbourne, Parkville, VIC). Retrieved from http://hdl.handle.net/11343/39898

Murrell, C. (2014). The vulture club: International newsgathering via Facebook. Australian Journalism Review, 36(1), 15-27. Retrieved from http://search.informit.com.au/ documentSummary; $\mathrm{dn}=502801913037134$;res=IELLCC

Newsmodo. (2014, September 20). Current briefs

Newsmodo. (2015, May 12). Newsmodo journalist Anna Bragga writes about a young woman's escape from sex slavery to ISIS Aussie terrorist for News Ltd [Facebook post]. Retrieved from www.facebook.com/newsmodo/posts/784099855019202

Peter, T.A. (2014, August 26). Why I decided war reporting was no longer worth the risk. New Republic. Retrieved from https://newrepublic.com/article/119222/journalistkidnapped-syria-reacts-isiss-james-foley-beheading

Pollard, R. (2009, December 12). In the shadow of Arroyo's warlords. Sydney Morning Herald. Retrieved from www.smh.com.au/world/in-the-shadow-of-arroyos-warlords20091211-kokt.html

Robie, D. (2014). Don't spoil my beautiful face: Media, mayhem and human rights in the Pacific. Auckland: Little Island Press.

Rory Peck Trust. (ca. 2013). 2013 Review and awards [brochure]. Retrieved from https:// rorypecktrust.org/getmedia/f2db7b4d-6eae-43ee-b87a-d640f49347f8/Rory_Peck_ Awards_2013_lo.pdf.aspx

Rory Peck Trust. (2014). Risk Assessment Notes 1. Retrieved from http://low.rorypecktrust.org/resources/safety-and-security/risk-assessment/Risk-Assessment-Notes-1

Rottwilm, P. (2014). The future of journalistic work: Its changing nature and implications. Reuters Institute for the Study of Journalism. Retrieved from http://reutersinstitute.politics.ox.ac.uk/sites/default/files/The $\% 20$ Future $\% 20$ of $\% 20$ Journalistic $\% 20$ Work $\% 20-\% 20$ Its $\% 20$ Changing\%20Nature\%20and $\% 20$ Implications.pdf

Sara, S. (2014, October 12). The return: One correspondent's personal experience with trauma. Correspondents Report, ABC Radio National. Retrieved from www.abc.net. $\mathrm{au} /$ correspondents/content/2014/s4105025.htm

Schultz, I. (2007). The journalistic gut feeling: Journalistic doxa, news habitus and orthodox news values. Journalism Practice, 1(2), 190-207. doi:10.1080/17512780701275507

Stelter, B. (2011, April 28). CBS reporter recounts a 'merciless' assault. The New York Times. Retrieved from www.nytimes.com/2011/04/29/business/media/29logan.html Taibi, C. (2014, September 18). AFP says it will no longer accept work from journalists who 
travel to Syria. The Huffington Post. Retrieved from www.huffingtonpost.com.au/entry/ afp-journalists-isis-foreign-reporters-iraq-syria_n_5844416.html?section=australia

United Nations. (2013, July 17). Veteran journalists, UN deputy chief urge Security Council to do more to protect reporters. UN News Centre. Retrieved from www. un.org/apps/news/story.asp?NewsID=45435

Verbossen, G. (2014). Collateral damage: Peter Greste and Egypt's information war. Griffith Review, 45, 4-9. Retrieved from https://griffithreview.com/wp-content/uploads/ GriffithREVIEW45 WWK.pdf

Weiss, J. (2013, May 17). Preparing to report from a conflict zone. IJNet. Retrieved from https://ijnet.org/en/blog/preparing-report-conflict-zone

Williams, P. (2014, September 15). MH17: Covering aftermath of Malaysia Airlines crash 'simply horrific', says ABC correspondent Philip Williams. Correspondents Report, ABC Radio National. Retrieved from www.abc.net.au/news/2014-09-14/ covering-the-mh17-aftermath-horrific-says-phil-williams/5742142

Wroe, D. (2014, September 22). Islamic State followers urged to attack Australians by any means possible. Sydney Morning Herald. Retrieved from www.smh.com.au/ federal-politics/political-news/islamic-state-followers-urged-to-attack-australiansby-any-means-possible-20140922-10kg74.html

The author thanks the collegiality of Monash University's Dr Fay Anderson, Deakin University's DrColleen Murrell, and the everywhere Queensland academic Trina Mclellan who all spoke to her about their work in this area.

DrAlexandra Wake brings 30 years of journalism and 15 years of teaching experience in formal education settings in Australia, Ireland, South Africa, the United Arab Emirates and in the Pacific. She has been elected six times to the national executive of the Journalism Education and Research Association, is on the education advisory board for the Hunter Mental Health Institute's Mindframe program, and was an academic fellow for the Dart Center for Journalism and Trauma. She has presented research papers at the past two World Journalism Education Congresses in Belgium and South Africa. Her research work is focused on the teaching of practical journalism skills. alex.wake@rmit.edu.au 